\title{
Hepatitis $C$ virus genotyping in relation to neu- oncoprotein overexpression and the development of hepatocellular carcinoma
}

\author{
ABDEL-RAHMAN N. ZEKRI, ABEER A. BAHNASSY*, SABRY M. SHAARAWY $\dagger$, OSSAMA A. \\ MANSOUR\|, MOHAMED A. MADUAR $\$$, HUSSEIN M. KHALED $\S$ and OMER EL-AHMADI\| \\ Virology and Immunology Unit, *Tissue Culture Unit, Pathology Department, †Biochemistry Unit, Cancer \\ Biology Department, National Cancer Institute, Cairo University, \$Tropical Medicine Department, Ain Shams \\ University, §M edical Oncology Department, National Cancer Institute, Cairo University and ||Biochemistry \\ Department, Faculty of Pharmacy, Al-Azhar University, Cairo, Egypt
}

\begin{abstract}
The distribution of hepatitis C virus (HCV) genotypes among Egyptian patients positive for anti-HCV was determined and their influence, when combined with neu-oncoprotein overexpression, on the development of hepatocellular carcinoma (HCC) was examined. The study groups included asymptomatic carriers (ASC) and patients with chronic active hepatitis (CAH) and HCC. HCV genomes were detected in the sera of 27 ASC, 29 $\mathrm{CAH}$ and $33 \mathrm{HCC}$ patients known to have HCV infection defined by EIA and recombinant immunoblotting techniques (Inno-LiA) as well as by reverse transcriptase (RT)-PCR. The HCV genotype was determined by a reverse hybridisation technique (I nno-LiPA I and II), whereas neu-overexpression was detected by the Oncogene Science EIA K it. Eighty-nine patients were eligible for HCV genotyping; 75 patients (84.3\%) were infected with a single genotype, including $1 \mathrm{a}$ in 11 patients $(12.4 \%), 1 \mathrm{~b}$ in 2 patients $(2.2 \%)$ and $2 \mathrm{a}$ in 10 patients $(11.2 \%)$. G enotype $4(\mathrm{a}$ or $\mathrm{c}+\mathrm{d})$ was detected in 51 patients $(57.3 \%)$ and only one patient had genotype 10a (1.2\%). Fourteen patients $(15.7 \%)$ showed mixed infection; eight of them had $1 a+4(a$ or $c+d)$ and four had $2 a+4$ $(a$ or $c+d)$; the remaining two cases had $1 a+2 a$ and $1 b+2 a$. The results revealed an increased incidence of genotype 4 in $\mathrm{CAH}$ and HCC patients in comparison with ASC. There was also a significant overexpression of neu-oncoprotein in $\mathrm{CAH}$ and $\mathrm{HCC}$ patients compared with ASC, which was significantly associated with subtype 4 infection. The results suggest that infection with subtype la and 4 HCV may be considered a risk factor for the induction of neu-over expression and subsequent development of HCC.
\end{abstract}

\section{Introduction}

Hepatitis $C$ virus (HCV) is a positive-strand enveloped RNA virus that plays a major role in the development of chronic hepatitis and hepatocellular carcinoma (HCC). Since its discovery in 1988 and with the use of nucleotide sequencing techniques, it has become clear that there are markedly divergent nucleotide sequences among distinct isolates. Phylogenetic analysis has been used to classify HCV into at least six major genotypes on the basis of viral sequence homology in both the coding and non-coding regions of the genome. The geographic distribution of HCV

Received 2 March 1999; accepted 16 June 1999. Corresponding author: Dr A-R. N. Zekri (e-mail: egcs@ starnet.com.eg). genomes differs considerably. In Europe and the USA, HCV-1a and - 1 b, HCV-2a and $-2 b$, and HCV-3a are the commonest subtypes, whereas in Japan HCV subtypes $1 a$ and $3 a$ are virtually non-existent. Genotype 4 is prevalent in patients from Northern Africa and the $M$ iddle East, and types 5 and 6 have been identified in serum samples obtained from South Africa and Hong Kong, respectively [1]. However, the data associating HCV genotypes and subtypes or hepatitis C viraemia levels, or both, with demographic, biochemical and histological characteristics of asymptomatic carriers (ASC), chronic active hepatitis (CAH) and $\mathrm{HCC}$ patients are conflicting.

Hepatocarcinogenesis involves alterations in the concerted action of proto-oncogenes, growth factors and tumour suppressor genes. The presence of two conserved potential nuclear localisation signals and a 
DNA binding motif in the HCV core protein suggest a possible functional role as a gene regulatory element. Moreover, some studies suggest that this protein interacts with certain cellular proto-oncogenes at the transcription level, resulting in the promotion of cell proliferation and thus affecting normal hepatocyte growth. Therefore, the pathogenesis of HCC may be attributed at least in part to the upregulation of hepatocyte growth induced by HCV core protein [2]. It has also been reported that the core protein activates the c-myc promoter and Rous sarcoma virus long terminal repeat, and suppresses the $\mathrm{Rb}$ gene $\beta$ interferon gene, $\beta$-actin gene and HIV-1 long terminal repeat [3]. It is also able to repress the transcriptional activity of the p53 promoter when tested in COS7 and HeLa cells [4], inhibit cisplatin and c-myc-mediated apoptotic cell death under certain conditions and transform primary rat embryo fibroblasts with a cooperative $\mathrm{H}$-ras oncogene [2]. In contrast, Chang et al. [5] were not able to detect transformation of primary rat fibroblasts with $\mathrm{HCV}$ core protein from two different genotype ( $1 a$ and $1 b$ ) in co-operation with $\mathrm{H}$-ras oncogene, even though the core protein was successfully expressed 20 days after transfection. However, the core protein was able to induce the transformation of rat-1 cells with various efficiencies depending on the expression level of the core protein. This clearly indicates that HCV core protein has an oncogenic potential to transform rat-1 cell line, but is not sufficient to either immortalise primary REFs by itself or to transform primary cells in conjunction with the $\mathrm{H}$-ras oncogene. As HCC develops over a period of $>20$ years [6], it is reasonable to speculate that $\mathrm{HCV}$ core protein is just one of a number of factors required for carcinogenesis or has a weak oncogenic activity which is sufficient to stimulate only a part of a complex, multistep pathway, or both [5].

One of the cellular oncogenes known to be important in the development of human malignancies is the neu (HER-2 or c-erbB-2) oncogene [7,8]. Amplification or overexpression, or both, of the neu oncogene has been implicated in experimental cellular transformation [9] and tumorigenesis in a wide range of human cancers including carcinoma of the breast, ovary, gastrointestinal tract, salivary glands, kidney, urinary bladder and liver [10].

The neu oncogene encodes a $185-\mathrm{kDa}$ transmembrane protein, which is structurally similar to the epidermal growth factor receptor [11]. The extracellular domain (ECD) of the p185 transmembrane growth factor receptor is released from the surface of human cancer cells that overexpress p185 and can be detected immunologically in the extracellular environment in vitro [12]. Similarly, it has been reported that overexpression of the c-erbB-2 oncogene can be detected immunologically in vivo by quantification of the ECD of p185 in the serum of human patients with cancers that are known to overexpress p185 $[13,14]$.
In a study on human hepatocellular carcinogenesis, it was possible to detect increased serum levels of p185 ECD (neu oncopeptide) in the individuals who eventually developed cancer 60 months before clinical diagnosis, indicating that serum neu-oncopeptide may be a useful biomarker for early detection of HCC [15]. It was also reported that elevated serum levels of neuoncoprotein correlate with the increased expression of this oncoprotein in tumour tissue [16, 17], suggesting that the serum level of neu-oncoprotein can be used as an indicator of its tissue expression.

Therefore, the current study was conducted to determine the serum levels of neu-oncoprotein in patients with $\mathrm{HCC}$ and $\mathrm{CAH}$, as well as in ASC who have ongoing HCV infection confirmed by EIA, immunoblotting and RT-PCR. The distribution of HCV genotypes in the Egyptian patients, as well as the correlation of the HCV genotype with neu-oncoprotein overexpression, were also studied in an attempt to understand the role of $\mathrm{HCV}$ in the development of $\mathrm{HCC}$ and to assess the feasibility of using antibodies against neu oncoprotein as immunotherapy for targeting cancer cells.

\section{M aterial and methods}

\section{Patients and controls}

Serum samples were collected from 33 patients with $\mathrm{HCC}$ and 29 patients with $\mathrm{CAH}$ as well as from 27 ASC. All patients were positive for anti-HCV antibodies as detected by EIA and immunoblotting techniques. Twenty serum samples from normal control subjects who were negative for anti-HCV antibodies were also included in the study. All serum samples obtained were re-analysed by EIA and immunoblotting (LiA) to confirm their reactivity for $\mathrm{HCV}$ antibodies. RT-PCR was also done to confirm HCV infection. The criteria for inclusion in the study groups were as follows. (a) ASC group: persistently normal alanine aminotransferase (ALT) values for 6 months and no detectable liver changes by sonography except for a bright fatty liver, which is common in the Egyptian population. (b) $\mathrm{CAH}$ group: (1) persistent increase of the ALT values more than three times normal for at least 6 months; (2) no evidence of hepatitis B virus (HBV) infection; (3) exclusion of other causes of chronic liver disease such as alcoholism or hepatotoxic drugs; (4) histopathological examination of core needle biopsies. Accordingly, patients were classified into 12 mild, 10 moderate and 7 severe cases of $\mathrm{CAH}$. (c) HCC group: HCC neoplastic cells were identified histopathologically in $H \& E$-stained sections of a core needle biopsy. Cases were classified into G1 (8 cases), G2 (22) and $G 3(3)$. None of the members of this group showed evidence of HBV infection by serological markers. Those patients in the three groups with an untypable genome were excluded from the study. 
Anti-HCV EIA

Samples from the three study groups were tested with a commercially available EIA (A bbott HCV EIA-2; A bbott Diagnostic Division, USA).

\section{Anti-HCV immunoblot assay}

Anti-HCV EIA-positive samples were tested by a synthetic immunoblot assay (LiA Tek; Organon Teknika) for confirmation of the results as described by the manufacturer.

\section{RNA extraction}

HCV RNA was extracted from the sera as described by Boom et al. [18].

\section{Oligonucleotide primers}

The RT and PCR were performed with a primer pair selected from the highly conserved 5-UTR part of the HCV genome according to Choo et al. [19]. The sequences used as antisense primers for C-DNA synthesis were HCV-6 [5-ACC-TCC nucleotides (nt) 319-324]. The internal primers for amplification of 266 bp of the 5-UTR were RB6A [5-GTG AGG AAC TAC TGT CTT CAC G-3 (nt 47-68)] and RB6B [5ACT CGC AAG CAC CCT ATC AGG (nt 292-312)].

\section{RT-PCR of HCV}

Reverse transcription was performed in a $25-\mu l$ reaction volume containing: $20 \mathrm{U}$ of RNA ase inhibitor (Promega Biotec Madison, WI, USA), $67 \mathrm{~mm} \mathrm{Tris-HCI}$ $(\mathrm{pH}$ 8.8), $17 \mathrm{mM}$ ammonium sulphate, $1 \mathrm{mM} \beta$ mercaptoethanol, $6 \mathrm{~mm}$ EDTA (pH 8.0), bovine serum albumin (Boehringer) $0.2 \mathrm{mg} / \mathrm{ml}, 6 \mathrm{mM} \mathrm{M} \mathrm{gCl} 2,25 \mathrm{ng}$ of primer HCV-6, $0.6 \mu \mathrm{l}$ of $25 \mathrm{~mm}$ (each) deoxynucleoside triphosphate, $11.5 \mu \mathrm{l}$ of the nucleic acid eluate and $200 \mathrm{U}$ of superscript-II RNA ase-H reverse transcriptase (Gibco-BRL, Gaithersburg, MD, USA). The mixture was incubated at room temperature for $5 \mathrm{~min}$ and then at $42^{\circ} \mathrm{C}$ for $60 \mathrm{~min}$. RT was denatured by incubation for $5 \mathrm{~min}$ at $95^{\circ} \mathrm{C}$. The PCR was performed in a $50-\mu l$ volume containing: $2.5 \mathrm{U}$ of Taq polymerase (PerkinElmer Cetus), $50 \mathrm{~mm}$ Tris $\mathrm{HCl}(\mathrm{pH} \mathrm{8.3),} 20 \mathrm{mM} \mathrm{KCl}$, $1.5 \mathrm{mM} \mathrm{M} \mathrm{gCl}$, bovine serum al bumin (BSA) $1 \mathrm{mg} / \mathrm{ml}$, $12.5 \mu \mathrm{l}$ of the RT reaction mixture, $200 \mu \mathrm{M}$ (each) deoxynucleoside triphosphate and $100 \mathrm{ng}$ each of primers RB-6A and RB-6B. Samples were denatured at $95^{\circ} \mathrm{C}$ for $5 \mathrm{~min}$ and subjected to 35 rounds of thermal cycling in a DNA thermal cycler (Type 480: Perkin-EImer Cetus). Each cycle consisted of denaturation for $1 \mathrm{~min}$ at $95^{\circ} \mathrm{C}$, annealing for $1 \mathrm{~min}$ at $55^{\circ} \mathrm{C}$, and extension for $2 \mathrm{~min}$ at $72^{\circ} \mathrm{C}$. After the cycling program samples were incubated for $10 \mathrm{~min}$ at $72^{\circ} \mathrm{C}$. As samples were analysed twice for HCV RNA by the RT-PCR on different days to ensure reproducibility of the result. After completion of the amplification reaction, $10 \mu \mathrm{l}$ of each PCR reaction product were analysed by electrophoresis through an agarose 1.2\% gel stained by ethidium bromide in Tris-acetate-EDTA buffer ( $\mathrm{pH} \mathrm{8.0)}$ and DNA was transferred from the gel on to a nitrocellulose filter with alkaline buffer ( $4 \mathrm{~N}$ $\mathrm{NaOH}$ ). The transferred DNA was cross-linked by incubation for $2-3 \mathrm{~h}$ at $80^{\circ} \mathrm{C}$ and the blot was then hybridised with an internal probe [20].

\section{HCV genotyping}

The line probe assay was used to determine the HCV genotype as described previously [21] with Inno-LiPA I and II.

\section{Neu ELISA}

The human neu-oncoprotein ELISA (Oncogene Science, NY, USA) was used to measure the neu protein product in sera by a sandwich ELISA, which utilises a mouse monoclonal antibody for capture and a rabbit polyclonal serum for the detection of human neuprotein, according to the manufacturer's instructions.

\section{Histological studies of liver}

Liver core needle biopsies (at least $10 \mathrm{~mm}$ long) from $\mathrm{CAH}$ and HCC patients who participated in the study were examined by two independent pathologists. Biopsy specimens were assessed for fibrosis (score $0-4$ ) and activity (score $0-18$ ) according to the scoring system of Knodell. Chronic hepatitis $\mathrm{C}$ was defined as mild if the total score was $<6$, moderate if the score was between 6 and 9 , and severe if the score was $>9$.

\section{Results}

The clinical characteristics of the $27 \mathrm{ASC}, 29 \mathrm{CAH}$ and 33 HCC patients are shown in Table 1. Male predominance was observed in all study groups and in particular the HCC patients $(90.9 \%)(p=0.0512)$.

The frequency of HCV genotypes for the 89 patients analysed is shown in Table 2. Seventy-five patients $(84.3 \%)$ were infected with a single genotype, including $1 \mathrm{a}$ in 11 patients (12.4\%), $1 \mathrm{~b}$ in 2 patients $(2.2 \%)$, $2 a$ in 10 patients $(11.2 \%), 4$ (a or $c+d)$ in 51 patients $(57.3 \%)$ and $10 \mathrm{a}$ in a single patient (1.2\%). On the other hand 14 patients $(15.7 \%)$ showed mixed infection, eight patients had $1 a+4(a$ or $c+d)$, four patients had $2 a+4(a$ or $c+d)$ and the remaining 2 patients had $1 a+2 a$ and $1 b+2 a$ subtypes.

On the basis of the line probe assay, the distribution of various HCV genotypes in ASC groups revealed that type la (8 patients, $29.6 \%$ ) and type 4 (8 patients, $29.6 \%)$ were the commonest genotypes followed by type 2 a ( 6 patients, $22.3 \%$ ). In comparison, genotype 4 was the predominant subtype in patients with $\mathrm{CAH}$ and 
Table 1. Clinical features of the study groups

\begin{tabular}{|c|c|c|c|c|}
\hline Characteristic & $\mathrm{ASC}^{*}$ & $\mathrm{CAH}$ & $\mathrm{HCC}$ & Control \\
\hline $\begin{array}{l}\text { Number of patients } \\
\text { M en/women }{ }^{\dagger} \\
\text { M ean age (SD) }\end{array}$ & $\begin{array}{c}27 \\
21 / 6 \\
37.4(7.8)\end{array}$ & $\begin{array}{c}29 \\
19 / 10 \\
43.9(9.5)\end{array}$ & $\begin{array}{c}33 \\
30 / 3 \\
54.4(10.5)\end{array}$ & $\begin{array}{c}20 \\
12 / 8 \\
37.7(8.6)\end{array}$ \\
\hline $\begin{array}{l}\text { Mode of transmission } \\
\text { Blood transfusion-related } \\
\text { Occupational } \\
\text { Intravenous drug use } \\
\text { Sporadic } \\
\text { Sexual } \\
\text { Not documented } \\
\text { M ean serum ALT level (SD) }\end{array}$ & $\begin{array}{c}14 \\
1 \\
0 \\
2 \\
0 \\
10 \\
26.4(7.0)\end{array}$ & $\begin{array}{c}11 \\
2 \\
0 \\
3 \\
0 \\
13 \\
149.1(125)\end{array}$ & $\begin{array}{c}14 \\
4 \\
0 \\
4 \\
1 \\
10 \\
120(114)\end{array}$ & $\begin{array}{c}0 \\
0 \\
0 \\
0 \\
0 \\
0 \\
24.2 \quad(4.2)\end{array}$ \\
\hline
\end{tabular}

Table 2. The frequency of HCV genotypes in the study groups

\begin{tabular}{lccccccc}
\hline & \multicolumn{7}{c}{ Number (\%) of patients with genotype } \\
\cline { 2 - 8 } Group & $1 \mathrm{a}$ & $1 \mathrm{~b}$ & $2 \mathrm{a}$ & 4 (a and c+d) & $10 \mathrm{a}$ & M ixed & Total \\
\hline ASC & $8(29.6)$ & 0 & $6(22.3)$ & $8(29.6)$ & 0 & $5(18.5)$ & 27 \\
CAH & 0 & 0 & $3(10.4)$ & $20(68.9)$ & $1(3.4)$ & $5(17.3)$ & 29 \\
HCC & $3(9.0)$ & $2(6)$ & $1(3)$ & $23(69.7)$ & 0 & $4(12.1)$ & 33 \\
Total & $11(12.4)$ & $2(2.2)$ & $10(11.2)$ & $51(57.3)$ & $1(1.1)$ & $14(15.7)$ & 89 \\
\hline
\end{tabular}

HCC, representing 20 patients $(68.9 \%)$ and 23 patients $(69.7 \%)$, respectively.

Serum neu-oncoprotein levels were determined by EIA and reported as human neu units $(\mathrm{HNU}) / \mathrm{ml}$ of serum. The cut-off value at which serum neu levels were considered elevated in this study was designated as $4164 \mathrm{HNU} / \mathrm{ml}$, a value $2 \mathrm{SD}$ in excess of the mean of the control group (Table 3).

A statistically significant difference in the mean serum levels of neu-oncoprotein was observed between both $\mathrm{HCC}$ and $\mathrm{CAH}$ patients when each was compared with the control group ( $F$ test $=15.801, p=0.001$ ), whereas no statistically significant difference was found in the mean neu-oncoprotein serum level between the $\mathrm{CAH}$ and HCC groups or between the ASC group and the control group.

Correlation between neu-overexpression and HCV genotype in the study groups

Both HCV type 4 and neu-oncoprotein overexpression were simultaneously encountered in $4(50 \%)$ of $8 \mathrm{ASC}$, $14(70 \%)$ of $20 \mathrm{CAH}$ and $21(91.3 \%)$ of $23 \mathrm{HCC}$ patients, whereas neu overexpression was not detected with any other subtypes (1a, 2a and 10a) except in one of the two cases with subtype $1 b$. Thirteen of the 14 patients with mixed infection were positive for neuoncoprotein overexpression, all of them having subtype 4 as a part of their mixed infection pattern. The remaining case, which was negative for neu-oncoprotein overexpression, had subtypes $1 a+2 a$. These findings illustrate that subtypes 4 and $1 b$ were frequently associated with neu-oncoprotein overexpression and the development of a progressive liver disease.

There was no significant difference between neuoncoprotein overexpression and either the sex of the patient or the grade of $\mathrm{CAH}$ and $\mathrm{HCC}$ (the $\mathrm{p}$ value of the latter was 0.9918). However, patients with elevated neu overexpression showed higher ALT values $(p=$ 0.0051).

\section{Discussion}

On the basis of nucleotide sequence homology, research groups have classified HCV into several genotypes by a number of nomenclature systems with different criteria

Table 3. Mean values and distribution of neu-oncoprotein overexpression in the study groups

\begin{tabular}{lcccc}
\hline Group & $\begin{array}{c}\text { Number of } \\
\text { subjects }\end{array}$ & M ean (SD)* & Range & Neu $^{\dagger}$ \\
\hline ASC & 27 & $3082(1313)$ & $1235-5867$ & $8(29.6 \%)$ \\
CAH & 29 & $4453(1245)$ & $1052-6624$ & $19(65.5 \%)$ \\
HCC & 33 & $4727(1011)$ & $2624-6129$ & $26(78.8 \%)$ \\
Controls & 20 & $3038(563)$ & $2175-3928$ & $3(15 \%)$ \\
\hline
\end{tabular}

*F test $=15.801, p=0.001$. 
[22]. M ethods for genotyping have included amplification of certain genomic regions and nucleotide sequencing [23], PCR with genotype-specific primers [24], restriction fragment length polymorphism (RFLP) analysis of the PCR amplicons [25], differential hybridisation [26] and serological typing [27]. The use of different methodologies and genomic regions for genotyping raises concern as to whether results based on different assays can be compared. Lau et al. [22, 28] found that a line probe assay based on the 5-UTR was sensitive and reproducible and had good concordance with other methods. Therefore this genotyping assay was used in the present study to allow standardisation and accurate comparison with other studies.

There are no previously published data regarding the distribution of $\mathrm{HCV}$ genotypes in relation to disease progression from $\mathrm{ASC}$ to $\mathrm{CAH}$ and $\mathrm{HCC}$ in the Egyptian population. In this study, type 4 was reported as the predominant $\mathrm{HCV}$ genotype in $\mathrm{CAH}(69 \%)$ and HCC (70\%), but not in ASC (30\%), in which subtype 4 had approximately equivalent prevalence to other subtypes (1a, 2a; $30 \%)$. The only case of subtype $10 a$ that was detected in this study was a patient with $\mathrm{CAH}$, indicating the rarity of this subtype among Egyptians. These data indicate that HCV subtype 4 is the most prevalent in Egyptian patients with chronic or malignant liver disease. On the other hand, genotypes $1 \mathrm{a}, 1 \mathrm{~b}$ and $2 a$ were detected in $12.4 \%, 2.2 \%$ and $11.2 \%$, respectively. These figures contrast with USA figures of la $(52.6 \%), 1 b(26.3 \%), 2(7.7 \%), 3 a(2.6 \%)$ and 4 $(2.6 \%)(29)$ and European figures of $1 \mathrm{~b}(43-68 \%), 2$ $(27 \%)$ and $3(6 \%)[30,31]$. These data al so support the results of the present study regarding the predominance of HCV type 4 in the Egyptian population.

Fourteen $(15.7 \%)$ of the 89 patients studied harboured mixed infection and genotype 4 was present in 13 of these. However, mixed infection has been reported in only $2 \%$ and $3.7 \%$ of European and USA series, respectively $[22,32]$. This difference in incidence rates may reflect a different mode of $\mathrm{HCV}$ transmission or it may be related to the methodology used. The line probe assay, used in the present study, relies on differential hybridisation of PCR amplicons derived from the 5-UTR, which is probably more sensitive in identifying mixed infection than other genotyping methods that amplify less conserved regions of the genome [22].

The present study also found that HCC patients were older than individuals in the ASC group although the same genotypes were evident in both groups, in agreement with $\mathrm{Kew}$ et al. [33]. This could be attributed either to depletion in the immune mechanisms in relation to age or to the relatively long duration of chronic liver disease that precedes the development of HCC in HCV-infected patients [33, 34].

This study provides direct evidence for the more aggressive course of liver disease as a result of infection by subtypes 4 and $1 \mathrm{~b}$ compared with other HCV subtypes. This may be attributed either to the higher replication rate of these subtypes, which subsequently leads to earlier recurrence and more severe liver disease, or to the possibility that the viral genome in these types may encode for protein(s) with an enhanced cytopathic effect on liver cells. It has been reported that modifications in the processing of some pestivirus encoded non-structural proteins can generate an enhanced cytopathic effect [35] and that amino-acid changes in HCV proteins are caused by immune selection. It is also plausible that different HCVencoded epitopes interact differently with the hosts immune response. Furthermore, several studies have shown significant variability in the HCV genome during the course of HCV infection in a given subject [30]. Feray et al. [30] found that infection with HCV type $1 b$ is associated with more severe recurrent liver disease after transplantation than other HCV genotypes. However, the demonstration that HCV-subtype 4 is differentially distributed among the disease categories of HCV-infected patients has not been documented previously.

In all, $79 \%$ of HCC (26 of 33 ) and $65 \%$ of CAH (19 of 29) patients showed high expression levels of neuoncoprotein in their sera, which is in agreement with Yu et al. [15], who demonstrated frequent overexpression of neu-oncoprotein in HCC patients. In spite of the lack of correlation between the biochemical parameters, clinical, virological and histological features of patients with different HCV subtypes, there is a significant difference in neu-oncogene expression between patient groups as well as between genotypes.

In several studies, neu-oncoprotein overexpression in the tumour tissue has been analysed and found to correlate with the elevation of its serum level $[17,36-$ 38]. Thus, it seems likely that the source of increased serum neu-oncoprotein in the patients included in these studies is their affected liver tissue [17]. The present study found that serum neu-oncoprotein levels in HCC and $\mathrm{CAH}$ patients were significantly higher than those in ASC and normal controls, but did not find any significant difference between neu-oncoprotein level between $\mathrm{HCC}$ and $\mathrm{CAH}$ patients. The exact role of neu-oncoprotein overexpression in hepatocarcinogenesis remains to be defined. The elevated expression of neu-oncoprotein may simply reflect the increased cell proliferation in preneoplastic liver tissue or in association with the cellular degeneration and necrosis that are characteristic of chronic liver disease. A Iternatively the increased expression may result from exposure to carcinogens in the course of hepatocarcinogenesis, of which HCV may be an important element. This is supported by the close association between elevated serum levels of neu-oncoprotein and HCV infection as putative $\mathrm{HCC}$ risk factors observed in this study and that of $\mathrm{Yu}$ et al. [15]. 
In conclusion, HCV genotype 4 represents the most dominant subtype in Egyptian patients (57.3\%) followed by subtypes $1 \mathrm{a}(12.4 \%)$ and $2 \mathrm{a}(11.4 \%)$. There is a significant elevation in the expression of neuoncoprotein in $\mathrm{CAH}$ and $\mathrm{HCC}$ compared with ASC and this elevation is significantly associated with infection by subtypes 4 and $1 b$. The results suggest that neu-oncoprotein may be elevated at an early stage of development of chronic liver disease as a result of infection by viral subtypes 4 and $1 b$, since it could also be detected in sera of ASC who harboured these subtypes of HCV. Hence, it is proposed that HCV infection with these subtypes may induce neu-oncoprotein overexpression which stimulates signal transduction, enhancing the proliferative activity and consequently the liability of random mutations and possibly malignant transformation of hepatocytes. The odds ratio of $\mathrm{CAH}$ and HCC patients having HCV type 4 is 6.55 (95\% confidence interval 1.78-25.37). The association between types 4 and $1 \mathrm{~b}$ and neu-overexpression in both $\mathrm{CAH}$ and $\mathrm{HCC}$ confirms the role of these subtypes in the induction of a more aggressive form of liver disease and addresses an important question regarding the presence of another co-factor which is required for the transformation of $\mathrm{CAH}$ into overt malignancy.

\section{References}

1. Gome ZJ, M artell M, Guardia S. Hepatitis C. In: Esteban JI, Wilson RA (eds) Viral hepatitis: diagnosis, treatment, prevention. New York, Marcel Dekker. 1997: 147-216.

2. Ray RB, lagging LM, M eyer K, Ray R. Hepatitis C Virus core protein cooperates with ras and transforms primary rat embryo fibroblasts to tumorigenic phenotype. J Virol 1996; 70: 44384443.

3. Ray RB, Lagging LM, M eyer K, Steele R, Ray R. Transcriptional regulation of cellular and viral promoters by the hepatitis C virus core protein. Virus Res 1995; 37: 209-220.

4. Ray RB, Steele R, M eyer K, Ray R. Transcriptional repression of p53 promoter by hepatitis $C$ virus core protein. J Biol Chem 1997; 272: 10983-10986.

5. Chang J, Yang S-H, Cho Y-G et al. Hepatitis C virus core from two different genotypes has an oncogenic potential but is not sufficient for transforming primary rat embryo fibroblasts in cooperation with the H-ras oncogene. J Virol 1998; 72: 30603065.

6. Di Bisceglie AM, Simpson LH, Lotze MT, Hoofnagle JH. Development of hepatocellular carcinoma among patients with chronic liver disease due to hepatitis C viral infection. J Clin Gastroenterol 1994; 19: 222-226.

7. Slamon DJ, Clark GM, Wang SG, Levin WJ, Velrich A, McGuire WL. Human breast cancer, correlation of relapse and survival with amplification of the HER-2/neu oncogene. Science 1987; 235: 177-182.

8. Press MF, Pike MC, Chazin VR et al. HER-2 neu expression in node-negative breast cancer: direct tissue quantitation by computerized image analysis and association of overexpression with increased risk of recurrent disease. Cancer Res 1993; 53 : 4960- 4970.

9. Hudziak RM, Schlessinger J, Ullrich A. Increased expression of the putative growth factor receptor P185 Her2 causes transformation and tumorigenesis of NIH3T3 cells. Proc Natl Acad Sci USA 1987; 84: 7159-7163.

10. King $C R$, Kraus $M H$, Difiore PP, Paik $S, K$ asprzyk PG. Implications of erbB-2 overexpression for basic science and clinical medicine. Semin Cancer Biol 1990; 1: 329-337.

11. Coussens L, Yang-Feng TL, Liao $Y-C$ et al. Tyrosine kinase receptor with extensive homology to $E G F$ receptor shares chromosomal location with neu oncogene. Science 1985; 230: $1132-1139$

12. Zabrecky JR, Lam T, McKenzie SJ, Carney W. The extracellular domain of $\mathrm{P} 185 /$ neu is released from the surface of human breast carcinoma cells, SK-BR-3. J Biol Chem 1991; 266: $1716-1720$

13. Carney WP, Hamer PJ, Petit D et al. Detection and quantitation of the human neu oncoprotein. J Tumor Marker Oncol 1991; 6: 53-72.

14. Jiin-Chyuan $L, M$ ing-Whei $Y, C$ hen-Jen $C$ et al. Serum C-erb B-2 oncopeptide in hepatocellular carcinogenesis. Med Sci Res 1993; 21: 305-307.

15. Yn M-W, Chen C-T, Luo J-C, Brandt-Rauf PW, Carney WP, Santella RM. Correlation of chronic hepatitis B virus infection and cigarette smoking with elevated expression of neu oncoprotein in the development of hepatocellular carcinoma. Cancer Res 1994; 54: 5106-5110.

16. B reuer B, Luo J-C, DeVivo I et al. Detection of elevated c-erb $\mathrm{B}-2$ oncopeptide in the serum and tissue in breast cancer. $\mathrm{Med}$ Sci Res 1993; 21: 383-384.

17. Brandt-Rauf PW, Luo J-C, Carney WP et al. Detection of increased amounts of the extracellular domain of the c-erbB-2 oncoprotein in serum during pulmonary carcinogenesis in humans. Int I Cancer 1994; 56: 383-386.

18. Boom R, Sole CJA, Salimans MMM, Jansen CL, Wertheimvan Dillen PME, Van der Noordaa J. Rapid and simple method for purification of nucleic acids. J Clin Microbiol 1990; 28: 495- 503.

19. Choo Q-L, Kuo G, Weiner AS, Overby LR, Bradley DW, Houghton $M$. Isolation of CDNA clone derived from a bloodbone non-A, non-B viral hepatitis genome. Science 1984; 244 359- 362.

20. Zekri A-RN, Bahnassy AA, Khaled HM, Mansour O, Attia $M A$. Comparative analysis of different PCR techniques for detection of $\mathrm{HCV}$ in hepatocellular carcinoma patients. Cancer J 1995; 8: 331-335

21. Stuyver $L$, Rossau R, Wyseur $A$ et al. Typing of hepatitis $C$ virus isolates and characterization of new subtypes using a line probe assay. J Gen Virol 1993; 74: 1093-1102.

22. $L$ au JYN, Davis $L G$, Prescott $L E$ et al. Distribution of hepatitis $C$ virus genotypes determined by line probe assay in patients with chronic hepatitis $\mathrm{C}$ seen at tertiary referral centers in the United States. Ann Intern Med 1996; 124: 868876.

23. Bukh J, Purcell RH, Miller RH. At least 12 genotypes of hepatitis $C$ virus predicated by sequence analysis of the putative El gene of isolates collected worldwide. Proc Natl Acad Sci USA 1993; 90: 8234-8238.

24. Chayama K, Tsubota A, A rase $Y$ et al. Genotyping subtyping of hepatitis C virus. J Gastroenterol Hepatol 1993; 8: 150156.

25. Nakao T, Enomoto N, Takada N, Takada A, Date T. Typing of hepatitis $\mathrm{C}$ virus genomes by restriction fragment length polymorphism. J Gen Virol 1991; 72: 2105-2112.

26. Takada N, Takase S, Enomoto N, Takada A, Date T. Clinical backgrounds of the patients having different types of hepatitis C virus genomes. J Hepatol 1992; 14: 35-40.

27. Simmonds $P$, Rose KA, Graham $S$ et al. Mapping of serotypespecific, immunodominant epitopes in the NS-4 region of hepatitis C virus (HCV): use of type-specific peptides to serologically differentiate infections with $\mathrm{HCV}$ types 1,2 , and 3. J Clin Microbiol 1993; 31: 1493-1503.

28. Lau JYN, Mizokami M, Kolberg JA et al. Application of six hepatitis $C$ virus genotyping systems to sera from chronic hepatitis C patients in the United States. J Infect Dis 1995; 171: 281-289.

29. Vargas HE, Wang L-F, Laskus $T$ et al. Distribution of infecting hepatitis $C$ virus genotypes in end-stage liver disease patients at a large A merican transplantation center. J Infect Dis 1997; 175: $448-450$

30. Féray C, Gigou M, Samuel $D$ et al. Influence of the genotypes of hepatitis $C$ virus on the severity of recurrent liver disease after liver transplantation. Gastroenterology 1995; 108: 1088- 1096.

31. Gane EJ, Portmann BC, Naoumov NV et al. Long-term outcome of hepatitis $\mathrm{C}$ virus infection of after liver transplantation. N Engl J Med 1996; 334: 815-820.

32. $M$ arinot-Peignoux $M, M$ arcellin $P$, Pouteau $M$ et al. Pretreatment serum hepatitis $C$ virus RNA levels and hepatitis $C$ virus genotype are the main and independent prognostic factors of 
sustained response to interferon alfa therapy in chronic hepatitis C. Hepatology 1995; 22: 1050-1056.

33. Kew MC, Yu MC, Kedda M-A, Coppin A, Sarkin A, Hodkinson J. The relative roles of hepatitis $B$ and $C$ viruses in the etiology of hepatocellular carcinoma in Southern A frican blacks. Gastroenterology 1997; 112: 184-187.

34. Nousbaum J-B, Pol $S, N$ alpas $S$ et al. Hepatitis $C$ virus type Ib (II) infection in France and Italy. Ann Intern Med 1995; 122: 161- 168.

35. Collett MS, Moennig V, Horzinek MC. Recent advances in pestivirus research. J Gen Virol 1989; 70: 253-266.
36. Mori S, Mori $Y, M u k a i y a m a ~ T$ et al. In vitro and in vivo release of soluble erbB-2 protein from human carcinoma cells. J pn J Cancer Res 1990; 81: 489-494.

37. Narita $T$, Funahashi $H$, Satoh $Y$, Takagi H. C-erbB-2 protein in the sera of breast cancer patients. Breast Cancer Res Treat 1993, 24: 97- 102.

38. Kynast $B, B$ inder $L, M$ arx $D$ et al. Determination of $a$ fragment of the c-erbB-2 translational product p185 in serum of breast cancer patients. J Cancer Res Clin Oncol 1993; 119: $249-252$. 